\title{
Evaluation of the Anti-Sickle Cell Activity of Uvaria Chamea P. Beauv. Roots Aqueous Extract
}

\author{
Lokonon Jacques Ezéchiel ${ }^{1}$, SENOU Maximin ${ }^{1}$, ABISSI Y. Gloria ${ }^{1}$, TCHOGOU Pascal $^{1}$, DEHOU René ${ }^{1}$, \\ MEDOATINSA Espérance ${ }^{1}$, KOUDORO Yaya ${ }^{3}$, AGBANGNAN Pascal ${ }^{3}$, ANAGO Eugénie ${ }^{2}$, AKPOVI D. Casimir ${ }^{2}$ \\ ${ }^{1}$ Laboratory of Experimental and Clinical Biology (LaBEC), National School of Applied Biosciences and \\ Biotechnologies (ENSBBA), National University of Sciences, Technologies, Engineering and Mathematics (UNSTIM), \\ R. Benin \\ 2 Laboratory of Applied Biology (LARBA), Polytechnic School of Abomey-Calavi (EPAC), University of \\ Abomey-Calavi (UAC), R Benin \\ ${ }^{3}$ Laboratory for Study and Research in Applied Chemistry (LERCA); Polytechnic School of Abomey-Calavi / University \\ of Abomey-Calavi (UAC), R. Benin \\ Correspondence: Sènou M, Experimental and Clinic Biology Laboratory, National School of Applied Biosciences and \\ Biotechnology, National University of Science, Technology, Engineering and Mathematics (UNSTIM), Dassa-Zoumé, R. \\ Benin
}

Received: July 30, 2021

Accepted: December 15, 2021

Online Published: January 27, 2022

doi:10.5539/ijb.v14n1p1

URL: https://doi.org/10.5539/ijb.v14n1p1

\begin{abstract}
Sickle cell disease was a very common hemoglobinosis in tropical countries. Several plants were used in traditional Beninese medicine to relieve sickle cell crises. The present work was carried out to test the efficiency of Uvaria chamea roots aqueous extract in the treatment of sickle cell crises.

Methods: Uvaria chamea roots aqueous extract was preincubated at different concentrations with blood cells from SS red blood cells before or after the Emmel Test. Intra-erythrocyte oxidative stress was measured by methaemoglobin assay after incubation of the extract with hemoglobin. In vivo, the action of the extract on Hemoglobin level, Mean Corpuscular Volume, and platelet count was measured in Wistar rats.

Results: The extract significantly prevented the formation of sickle cells at doses of 40 and $20 \mathrm{mg} / \mathrm{ml}$ of blood $(\mathrm{P}<0.05)$ and significantly reduced sickle cells to the normal biconcave form at the dose of $40 \mathrm{mg} / \mathrm{ml}(\mathrm{P}<0.05)$. It lowered the production of methemoglobin at a dose of $10 \mathrm{mg} / \mathrm{ml}$, suggesting antioxidant activity. Hemoglobin level, Mean Corpuscular Volume, and platelet count did not significantly increase in treated rats, indicating that the extract did not stimulate erythropoiesis or thrombopoiesis.

Conclusion: Uvaria chamea extract inhibited dose-dependent sickling of red blood cells. It reduced intraerythrocyte oxidative stress but did not show hematopoietic activity. It could therefore be considered in the preventive or curative management of sickle cell crises, but not against anemia.
\end{abstract}

Keywords: sickle cell disease, Uvaria chamea, anemia, Benin

\section{Introduction}

Hemoglobinopathies were genetic diseases with inherited abnormalities of hemoglobin. They were divided into two groups : the group of hemoglobinoses presenting structural abnormalities of the globin chain and that of thalassemias characterized by a deficit of one or more chains of hemoglobin. Some pathologies were composite and belong to both groups at the same time (Aubry, 2020). The prevalence of sickle cell trait fluctuated between $20 \%$ and $30 \%$ in affected countries with a high disease burden (WHO, 2020). In 2016, nearly 5\% of the world's population carried a gene responsible for a hemoglobin abnormality and each year, hundreds of thousands of infants were born around the world with thalassemia syndromes $(30 \%)$ or sickle cell disease $(70 \%)$. Sickle cell disease was among the most common monogenic diseases worldwide (Fatima et al., 2016). An estimated 312,000 people with SS hemoglobin were born each year worldwide, with the majority of these 236,000 births in sub-Saharan Africa (Piel et al., 2013). The management of sickle cell disease was not easy because the majority of affected countries were poor. 
At the same time, traditional medicine was the most widespread form of medicine that people turn to for treatment (WHO, 2002). Traditional medicine was very old. It was the sum of all the knowledge, skills and practices based on the theories, beliefs and experiences of different cultures, whether they were explainable or not, and which were used in the preservation of health, as well as in prevention, diagnosis, amelioration or treatment of physical or mental illnesses (WHO, 2013). Indeed, according to estimates, traditional medicine accounted for 80 to $90 \%$ of health care in Africa (WHO, 2002). In recent decades, herbal medicine research became of greater scientific concern (Niyah Njike et al., 2005). It was within this framework that this work aimed to experimentally test the effectiveness of the roots of Uvaria chamea used by traditional therapists in Benin in the management of sickle cell disease.

\section{Material and Methods}

\subsection{Plant Material and Aqueous Extraction}

The roots of Uvaria chamea were collected in Hêvié in the commune of Abomey-Calavi in Benin. The identification and certification of the plant was made at the National Herbarium of the University of Abomey-Calavi on number YH268 / HNB. The plant was dried at laboratory temperature $\left(20^{\circ}-25^{\circ}\right)$ out of direct sunlight and moisture for three weeks. They were then powdered and stored in black sachets (Koudoro et al., 2018 ; Tchogou et al., 2021). The technique used to prepare the extracts was that of maceration. After filtration, the extracts were evaporated to dryness at $60{ }^{\circ} \mathrm{C}$ using a Heidolph type rotary evaporator (Koudoro et al., 2018; Tchogou et al., 2021).

\subsection{Human Material}

Blood samples from ten (10) SS sickle cell patients were taken at the Zou / Collines departmental hospital in Benin with the consent of the patients after approval by the Ethics Committee of the National School of Applied Biosciences and Biotechnologies in Benin.

\subsection{Animal Material}

The animal material is comprised of six (6) strain albino Wistar female rats from the animal house of IBSA in Benin whose average weight is $143 \mathrm{~g}$. These rats were acclimatized to ambient rearing conditions in the animal facility of the Experimental and Clinical Biology Laboratory at the National School of Applied Biosciences and Biotechnologies in Benin. They had access to water and food. They are lit for 12 hours a day and have been put in spacious cages. The cage is cleaned regularly and the water is renewed very often. The behavior of the animals was observed during the two weeks of acclimatization.

\subsection{In Vitro Biological Tests}

\subsubsection{Identification of Secondary Metabolites}

The metabolites were identified by coloring and precipitation reactions specific to each metabolite family (Houghton et al., 1998; Agbangnan et al., 2012; Dohou et al., 2003; Koudoro et al., 2015).

\subsubsection{Hemoglobin Electrophoresis}

It is performed to determine the phenotypes of the blood samples taken and to ensure that they were of the SS phenotype. The principle is based on the difference in migration of hemoglobins in an electrophoretic field according to their electrical charges. It was carried out on cellulose acetate gel at pH 8.5 as previously reported (Mpiana et al., 2012).

\subsubsection{Anti-sickle Cell Activity}

\subsubsection{Emmel's Test}

The principle of the test was that in the absence of oxygen, hemoglobin S polymerizes giving rise to the formation of fibers which deform the blood cell and give it a sickle appearance. Between slide and coverslip, a drop of blood was deposited with $2 \%$ sodium metabisulphite. The test was positive if after an hour of time, the red blood cells took the shape of a sickle or banana with pointed, often serrated ends (Mpiana et al., 2013; Sènou et al., 2017).

Emmel's test was performed to assess the anti-sickle cell activity of the extracts. Volume-to-volume mixing was performed between the SS blood sample and physiological water on the one hand to constitute the control and between the blood sample and the extract on the other hand for the test. After 6 hours of incubation at room temperature in the laboratory, a drop of each mixture was mounted between slide and coverslip with a drop of $2 \%$ sodium metabisulphite, then the edges were coated with candle wax to prevent drying. The preparations were then read under an optical microscope 4 hours later and the erythrocytes of different shapes observed were counted.

Blood samples of SS phenotypes were mixed with the extract at different concentrations (5, 10, $20 \mathrm{and} 40 \mathrm{mg} / \mathrm{ml}) \mathrm{using}$ physiological saline as a solvent. 


\subsubsection{Emmel Reverse Test}

Blood samples of SS phenotypes were mixed with $2 \%$ sodium metabisulfite in equal volume and incubated for 2 hours at room temperature. To an aliquot of this mixture was added an equal amount of physiological water for the control or 40 $\mathrm{mg} / \mathrm{ml}$ extract for the test. After 6 hours of incubation at room temperature, the preparations were read under an optical microscope after mounting between slide and coverslip.

\subsubsection{Evaluation of the Ratio of Methemoglobin Production ( $\mathrm{Fe}++/ \mathrm{Fe}+++)$}

The principle was based on measuring the absorbance of methemoglobin at $540 \mathrm{~nm}$. The methemoglobin profile was a bioindicator of intra-erythrocyte oxidative stress in sickle cell patients (Kambale et al., 2013).

Sickle cell erythrocytes were washed with $0.9 \% \mathrm{NaCl}$ solution ( 5 volumes $\mathrm{NaCl}$ per 1 volume of well-homogenized whole blood). The mixture was homogenized by successive inversion, centrifuged at $3000 \mathrm{rpm}$ for 10 minutes.

The red blood cell pellet was hemolyzed by adding a double volume in double-distilled water and then centrifuged at high speed. The hemoglobin S solution thus obtained was mixed with the plant extract $(10 \mathrm{mg} / \mathrm{ml})$ incubated for 2 hours. For the negative control, the extract was replaced by physiological solution $(0.9 \% \mathrm{NaCl})$. The absorbances of the solution were read at $540 \mathrm{\eta m}$ at time intervals $(0,30,60,90$ and $120 \mathrm{~min})$ using a UV-visible spectrophotometer: six tubes were available for this (in duplicate) T0 (reading at start time), T30 (reading after $30 \mathrm{~min}$ ), T60 (reading after 60 min), T90 (reading after $90 \mathrm{~min}$ ) and T120 (reading after $120 \mathrm{~min}$ ). The change in optical density (delta OD) over time was calculated to quantify the formation or disappearance of methemoglobin (adapted from Kambale et al., 2013; Mpiana et al., 2007a, b, c).

\subsection{In Vivo Biological Tests}

In vivo, the effect of the extract of the roots of Uvaria chamea on the evolution of hemoglobin, mean corpuscular volume (MCV) and blood platelets was studied in female rats of the wistar strain. for this purpose, two groups of rats of three (3) rats each were formed. The first group being the control received physiological water by gavage and the second group received by gavage the extract of Uvaria chamea at $200 \mathrm{mg} / \mathrm{Kg}$ of body weight daily for 28 days.

\subsection{Blood Tests}

The blood of the rats of the two groups was taken at the beginning (D0) and on the twenty-eighth day (D28) by orbital puncture after ether anesthesia. The hemoglobin level and mean corpuscular volume (MCV) and the number of platelets were determined by automated system (Sènou et al., 2016; Agbogba et al., 2019).

\subsection{Statistical Analysis}

To assess the biological effect of the extract, Dunn's multi-comparison test and Mann Whitney test were used. The significance level was set at 5\%. The graphs were drawn using Graphpad software.

\section{Results}

\subsection{The Aqueous Extract of the Root of Uvaria Chamea P. Beauv Inhibited the Sickling of SS Red Blood Cells}

Figure 1 showed the mean rate of sickle observed depending on the concentration of the extract. The sickle cell levels were respectively $0.85 \pm 0.09$ for the controls $(0 \mathrm{mg}$ extract $/ \mathrm{ml}) ; 0.44 \pm 0.14$ for those treated at $40 \mathrm{mg} / \mathrm{ml} ; 0.60 \pm 0.09$ for the $20 \mathrm{mg}$ treated; $0.71 \pm 0.15$ for those treated with $10 \mathrm{mg}$ and $0.72 \pm 0.02$ for those treated with $5 \mathrm{mg}$. Uvaria chamea $\mathrm{P}$. Beauv extract significantly lowered sickle cell count at $40 \mathrm{mg}$ and $20 \mathrm{mg} / \mathrm{ml}$ compared to controls $(\mathrm{P}<0.05)$. Inhibition of Sickle Red Blood Cells appears to be dose-dependent.

\subsection{The Aqueous Extract of the Root of Uvaria Chamea P. Beauv Reversed the Sickling of SS Red Blood Cells}

Figure 2 showed the result of the Emmel reverse test. The average sickle cell count was $0.76 \pm 0.11$ for the controls and $0.48 \pm 0.09$ for the $40 \mathrm{mg}$ treated with Uvaria chamea $\mathrm{P}$. Beauv extract. The mean sickle cell count decreased significantly with the extract $(\mathrm{P}<0.05)$, indicating that the extract reversed sickle cell sickling.

\subsection{The Aqueous Extract of the Roots of Uvaria Chamea P. Beauv Reduced Intra-Erythrocyte Oxidative Stress}

Figure 3 showed the variation of methemoglobin in the blood of SS patients. After two hours, the absorbance of methemoglobin increased by $0.012 \pm 0.004$ for the controls while it decreased instead by $0.038 \pm 0.004$ with the extract of Uvaria chamea P. Beauv. at $10 \mathrm{mg} / \mathrm{ml}$. This decrease of methemoglobin indicated a reduction of oxidative stress in red blood cells by the aqueous extract Uvaria chamea.

\subsection{The Aqueous Extract of the Roots of Uvaria Chamea P. Beauv did not Stimulate Hematopoiesis}

Table 1 showed hemoglobin level, mean corpuscular volume and blood platelet count before and after the extract administartion to rats. 
The mean hemoglobin level was $15.4 \pm 0.3 \mathrm{~g} / \mathrm{dl}$ in control rats and $16.3 \pm 0.3 \mathrm{~g} / \mathrm{dl}$ in rats treated with Uvaria chamea $\mathrm{P}$. Beauv. The mean hemoglobin level did not change significantly between control rats and those treated with $U v e r i a$ chamea, indicating that the extract did not stimulate hemoglobin synthesis.

The mean corpuscular volume was $60 \pm 2 \mathrm{fL}$ in control rats and $61 \pm 1 \mathrm{fL}$ rats treated with Uvaria chamea P. Beauv. Mean corpuscular volume did not change significantly between controls and those treated rats Uveria chamea, indicating that the extract did not stimulate release of young red blood cells into the blood.

The mean number of blood platelets was $595 \pm 36 \mathrm{G} / 1$ in control rats and $574 \pm 29 \mathrm{G} / 1$ in rats treated with Uvaria chamea P. Beauv. The mean blood platelet count did not change significantly between control rats and those treated with Uveria chamea, indicating that the extract did not stimulate thrombopoiesis.

\subsection{Phytochemical Composition of Uveria Chamea Roots}

Table 2 showed the phytochemical screening of Uveria chamea roots. The screening revealed the presence of flavonoids, catechesis tannins, leucoanthocyanins and anthocyanins in the roots of Uvaria chamea. We also noted the absence of gallic tannins, saponins, reducing compounds, mucilages and alkaloids.

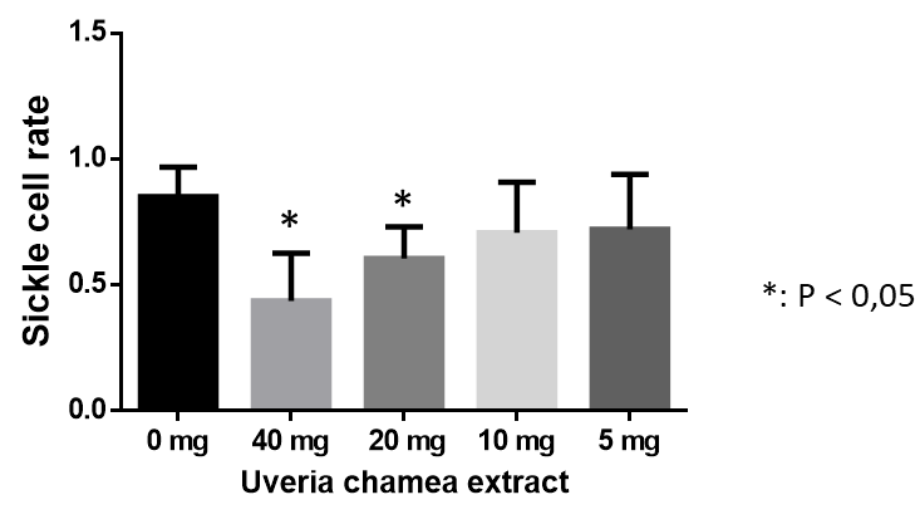

Figure 1. Mean sickle cell count in Emmel's test as a function of the extract concentration

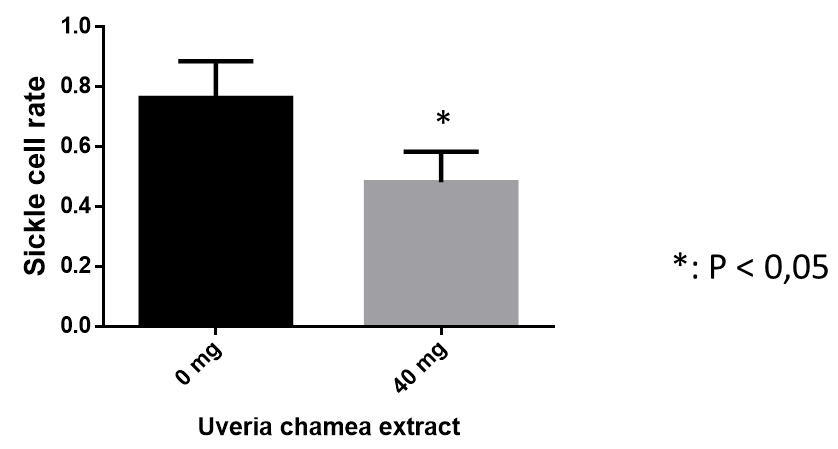

Figure 2. Mean sickle cell count on the Emmel reverse test

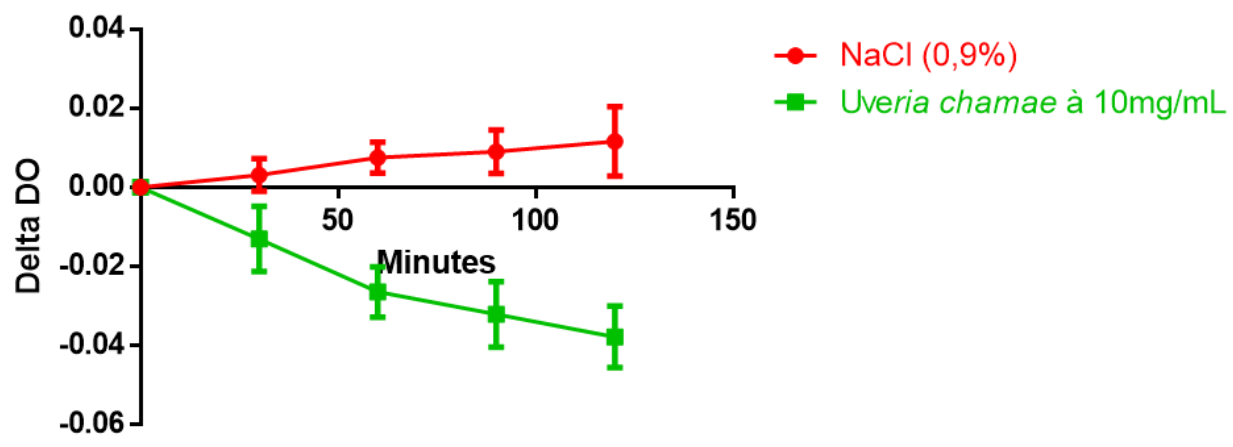

Figure 3. Change in methemoglobin production in SS red blood cells over time 
Table 1. Change in rats Hemoglobin level, Mean corpuscular volume and blood platelet count

\begin{tabular}{llll}
\hline Rats parameters & Day 0 & Day 28 & P value \\
\hline Hemoglobin level (g/dl) & $15.4 \pm 0.3$ & $16.3 \pm 0.3$ & 0.2 \\
Mean corpuscular volume (fl) & $60 \pm 2$ & $61 \pm 1$ & 0.7 \\
Mean blood platelet count (G/l) & $595 \pm 36$ & $574 \pm 29$ & 0.9 \\
\hline
\end{tabular}

Table 2. Phytochemical screening of Uveria chamea roots

\begin{tabular}{lc}
\hline Métabolites secondaires & Uveria chamea P. Beauv. \\
\hline Flavonoids & + \\
Catechetical tannins & + \\
Gallic tannins & - \\
Leucoanthocyanins & + \\
Anthocyanins & + \\
Saponosides & - \\
Reducing compounds & - \\
Mucilages & - \\
Alkaloids & - \\
\hline
\end{tabular}

\section{Discussion}

Sickle cell disease was a hemoglobinosis that is most common in tropical countries. This work was part of a search for remedies that can relieve victims of this pathology. Uvaria chamea was one of the plants used by Beninese traditional therapists for this purpose. Thus, the present work tested in vitro the effectiveness of the aqueous extract of the roots of the plant in preventing or correcting the sickling of S red blood cells, responsible for sickle cell disease crises.

The aqueous extract of Uvaria chamea at concentrations of 20 or $40 \mathrm{mg} / \mathrm{ml}$ significantly inhibited the formation of sickle cells by SS red blood cells under hypoxic conditions. The extract therefore prevented the polymerization of hemoglobin S and therefore the sickling of red blood cells, responsible for sickle cell crises (Ngbolua et al., 2013). This polymerization of hemoglobin into a tactoid leads to reduced glycolytic and ionic flow and cell dehydration (Mpiana et al., 2007). In addition to the preventive effect of the sickling of SS red blood cells, at $40 \mathrm{mg} / \mathrm{ml}$ the extract induced a conversion of sickle cells into normal biconcave red cells. This result showed that the aqueous extract of Uvaria chamea could depolymerize hemoglobin S under hypoxic conditions and therefore reverse the process of sickle cell formation. This suggests that it also has a curative effect and justifies its use in traditional medicine in the treatment of sickle cell crises. This property has also been mentioned in certain plants in Congo which inverted sickle cells into normal biconcave red blood cells (Ngbolua et al., 2013).

In order to explore the mechanism of action of the extract, we tested its effect on the production of methemoglobin. The aqueous extract of Uvaria chamea decreased production of methemoglobin in the SS red blood cells compared to control untreated SS erythrocytes. Indeed, various authors have shown that SS erythrocytes contain a greater concentration of methemoglobin than AA erythrocytes. However, methemoglobin contains oxidized iron $\left(\mathrm{Fe}^{3+}\right)$ which has less affinity for oxygen than hemoglobin $\left(\mathrm{Fe}^{2+}\right)$. Oxidation of hemoglobin $\left(\mathrm{Fe}^{2+}\right)$ to methemoglobin $\left(\mathrm{Fe}^{3+}\right)$ is due to significant oxidative stress in sickle cells (Mpiana et al., 2010; Ngbolua, 2012). Thus, a plant which would decrease the methemoglobin profile would therefore have an antioxidant effect on sickle cell red blood cells (Kambale et al., 2013). This suggests that the action of the aqueous extract of Uvaria chamea could be through a reduction in intra-erythrocyte oxidative stress. This result is similar to that obtained by et kambale (2013) who showed that Uapaca heudelotii Baill would prevent the oxidation of hemoglobin.

In order to elucidate whether the action of the extract did not induce stimulation of hematopoiesis to compensate for sickle cell anemia, we tested it in vivo by chronic administration in Wistar rats. Uvaria chamea root extract did not significantly increase hemoglobin level, Mean Globular Volume and blood platelet count in rats, indicating that its action did not involve stimulation of erythropoiesis or thrombopoiesis. This explains why its use in traditional medicine is coupled with other anti-anemic plants. This was the case of Cocos nucifera L. (Arecaceae) and Psorospermum febrifugum whose root aqueous extracts compensate for anemia by effectively stimulating hematopoiesis (Tchogou et al., 2016 ; Agbogba et al., 2019).

Phytochemical screening of the roots of Uvaria chamea revealed the presence of several secondary metabolites including anthocyanins. This family of chemical compounds was believed to be involved in inhibiting the polymerization of hemoglobin $\mathrm{S}$, thus preventing the sickling of erythrocytes. It would also act by stabilizing the erythrocyte membrane through its antioxidant properties (Mpiana et al., 2008; Mpiana et al., 2010; Ngbolua, 2012). The biological effects 
observed in the extract of the roots of Uvaria chamea could be due to anthocyanins and perhaps also to other families of compounds.

\section{Conclusion}

The aqueous extracts from the roots of Uvaria chamea prevent and reverse sickling of S red blood cells. It decreases intraerythrocytic oxidative stress without stimulating erythropoiesis and thrombopoiesis. Its action is believed to be due to the secondary metabolites it contains, including anthocyanins. It could therefore be considered in the preventive or curative treatment of sickle cell crises after verification of its safety.

\section{References}

Agbangnan, D. C. P., Tachon, C. B., Chrostowka, A., Fouquet, E., \&Sohounhloue, D. C. K. (2012). Phytochemical study of a tinctorial plant of benin traditional pharmacopoeia: The red sorghum (sorghum caudatum) of Benin". Scientific Study \& Research, 13(0.2), 121-135.

Agbogba, F., Sacramento, T. I., Tchogou, A. P., Medoatinsa, E., Kanfon, E. R., Atakpa, E., ... Sèzan A. (2019). The aqueous extract of the root bark of Psorospermum febrifugum Spach effectively corrects anaemia. Experimental study on Wistar rats. Journal of Applied Biosciences, 139, 14137 - 14146. https://dx.doi.org/10.4314/jab.v139i1.1

Alain, K. Y., Valentin, W. D., Christian, K. T., Pascal, A. D., \& Dominique, S. C. (2015). Phytochemical screening, antibacterial and anti-radical activities of Daniellia oliveri trunk bark extracts used in veterinary medicine against gastrointestinal diseases in Benin. International Journal, 3(10), 1190-1198.

Aubry P et Gauzere B-A. (2020). Hémoglobinoses. Médecine tropicale. Mise à jour du 15/10/2020. Pg 16. Retrieved from http://medecinetropicale.free.fr/cours/hemoglobinoses.

Dohou, N., Yamni, K., Tahrouch, S., Idrissi-Hassani, L. M., Badoc, A., \& Gmira, N. (2003). Screening phytochimique d'une endémique ibéro-marocaine, Thymelaea lythroides. Bulletin de la société pharmaceutique de Bordeaux, 142, 61-78.

Elion, J., \& Labie, D. (1996). Bases physiopathologiques moléculaires et cellulaires du traitement de la drépanocytose. Hématologie, 2(6), 499-510.

Fatima, D., Souad, B., Jaafar, K., Aziz, W., Hassan, M., Azlarab, M. (2016). Etude de 1'hémogramme dans la drépanocytose homozygote: à propos de 87 patients. Pan AfricaMedical Journal, $25,240$. http://www.panafrican-med-journal.com/content/article/25/240/full/

Houghton, P. J., \& Raman, A. (1998). Laboratory Handbook for the Fractionation of Natural Extracts. London: Chapman and Hall. pp.22-52.

Kambale, J. K., Ngbolua, K. N., MPIANA, P. T., Mudogo, V., Tshibangu, D. S. T., Wumba, D. M. R., ... EKUTSU, E. (2013). Evaluation in vitro de l'activité antifalcémiante et effet antioxydant des extraits d'Uapaca heudelotii Baill. (Euphorbiaceae). International Journal of Biological Chemical Sciences, 7(2), 523-534. http://dx.doi.org/10.4314/ijbcs.v7i2.9

Kapepula, P. M., Mukeba, F., Bopopi, J. M., Mayangi, M., Kikweta, C., Kitwa, F., ... Mbemba T. (2020). Selenium content, antibacterial, antioxidant and anti-sickling activities of Zanthoxylum gilletii (De Wild) P.G. Waterman (Rutaceae). Discovery Phytomedicine, 7(4). http://dx.doi.org/10.15562/phytomedicine.2020.141

Koudoro, Y. A., Agbangnan, D. P. C., Bothon, D., Bogninou, S. R., Alitonou, G. A., Avlessi, F., \& Sohounhloue, C. K. D. (2018). Métabolites secondaires et activités biologiques des extraits de l'écorce de tronc de Khaya senegalensis, une plante à usage vétérinaire récoltée au Bénin. International Journal of Innovation and Applied Studies. 23(4) : 441-450. http://dx.doi.org/10.21474/IJAR01/9927.

Mpiana, P. T., Lombe, B. K., Ombeni, A. M., Tshibangu, D. S., Wimba, L. K., Tshilanda, D. D., ... \& Muyisa, S. K. (2013). In vitro sickling inhibitory effects and anti-sickle erythrocytes hemolysis of Dicliptera colorata CB Clarke, Euphorbia hirta L. and Sorghum bicolor (L.) Moench.

Mpiana, P. T., Mudogo, V., Ngbolua, K. N., Tshibangu, D. S. T., Shetonde, O. M., \& Mbala, B. M. (2007a). In vitro Antisickling Activity of Anthocyanins from Ocimum basilicum L. (Lamiaceae), Int. J. Pharmacol, 3(4), $371-374$. https://dx.doi.org/10.3923/ijp.2007.371.374

Mpiana, P. T., Mudogo, V., Tshibangu, D. S. T., Kitwa, E. K., Kanangila, A. B., Lumbu, J. B. S., ... \& Kakule, M. K. (2008). Antisickling activity of anthocyanins from Bombax pentadrum, Ficus capensis and Ziziphus mucronata: photodegradation effect. Journal of ethnopharmacology, 120(3), 413-418. 
Mpiana, P. T., Mudogo, V., Tshibangu, D. S. T., Ngbolua, K. N., Shetonde, O. M., Mangwala, P. K., \& Mavakala, B. K. (2007). In vitro antisickling activity of anthocyanins extracts of a Congolese plant: Alchornea cordifolia M. Arg. Journal of Medical Sciences, 7(7), 1182-1186.

Mpiana, P. T., Ngbolua, K. N. N., Bokota, M. T., Kasonga, T. K., Atibu, E. K., Tshibangu, D. S., \& Mudogo, V. (2010). In vitro effects of anthocyanin extracts from Justicia secunda Vahl on the solubility of haemoglobin $S$ and membrane stability of sickle erythrocytes. Blood transfusion, 8(4), 248.

Mpiana, P. T., Ngbolua, K. N., Mudogo, V., Tshibangu, D. S. T., \& Atibu, E. K. (2012). In Progress in Traditional and Folk Herbal Medicine, vol. I, ed. by V.K. Gupta (Daya Publishing House, New Delhi, 2012), pp. 1-11.

Mpiana, P. T., Tshibangu, D. S. T., Shetonde, O. M., \& Ngbolua, K. N. (2007). In vitro antidrepanocytary actvity (anti-sickle cell anemia) of some congolese plants. Phytomedicine, 14(2-3), 192-195.

Ngbolua, K. N. (2012). Evaluation de l'activité antidrepanocytaire et antipaludique de quelques taxons végétaux de la RD Congo et de Madagascar (Doctoral dissertation, Thèse de Doctorat, Université de Kinshasa, Kinshasa, 300p).

Ngbolua, K. N., Mudogo, V., Mpiana, P. T., Malekani, M. J., Rafatro, H., Ratsimamanga, U., ... \& Tshibangu, D. S. T. (2013). Evaluation de l'activité anti-drépanocytaire et antipaludique de quelques taxons végétaux de la République démocratique du Congo et de Madagascar. Ethnopharmacologia, 50, 19-24.

Niyah Njike, G., Watcho, P., Nguelefack, T. B., \& Kamanyi, A. (2005). Hypoglycaemic activity of the leaves of Bersama engleriana in rats. Afr J Trad, 2, 215-221.

OMS (Organisation Mondiale de la Santé). (2002). Diabète sucré. Aide-mémoire; №138.

OMS, 2020. Progrès réalisés dans la mise en œuvre de la stratégie de lutte contre la drépanocytose dans la région africaine 2010-2020. Comité régional de l'Afrique, soixante-dixième session. Session virtuelle, 25 août 2020. Pg 5.

Piel, F. B., Patil, A. P., Howes, R. E., Nyangiri, O. A., Gething, P. W., Dewi, M., ... \& Hay, S. I. (2013). Global epidemiology of sickle haemoglobin in neonates: a contemporary geostatistical model-based map and population estimates. The Lancet, 381(9861), 142-151.

Sènou, M., Lokonon, J. E., Agbogba, F., Agbangnan, D. C. P., Odoulami, S., Tchogou, A. P., ... Loko, F. (2017). In vitro study of some characteristics of red blood cells with hemoglobin S. International Journal of Biosciences, 10(1), 311-317. http://dx.doi.org/10.12692/ijb/10.1.311-317.

Sènou, M., Tchogou, A. P., Dougnon, T. V., Agossadou, A., Assogba, F., Kinsiclounon, E. G., ... \& Loko, F. (2016). Efficiency of Sorghum bicolor extract in the treatment of induced anemia on Wistar rats. International Journal of Biosciences, 8(4), 62-71.

Tchogou, A. P., Sènou, M., Dougnon, T. V., Agossadou, A., Assogba, F., Kinsiclounon, E. G., ... \& Loko, F. (2016). The aqueous extract of Cocos nucifera L. (Arecaceae) effectively treat induced anemia. Experimental study on Wistar rats. International Journal of Biology, 8(3), 1-9.

Tchogou, A. P., Sènou, M., Dougnon, T. V., Agossadou, A., Assogba, F., Kinsiclounon, E. G., ... \& Loko, F. (2016). The aqueous extract of Cocos nucifera L. (Arecaceae) effectively treat induced anemia. Experimental study on Wistar rats. International Journal of Biology, 8(3), 1-9.

Tshilanda, D. D., Onyamboko, D. V., Mwanangombo, D. T., Tsalu, P. V., Misengabu, N. K., Tshibangu, D. S. T., ... \& Mpiana, P. T. (2015). In vitro antisickling activity of anthocyanins from Ocimum canun (Lamiacea). Journal of Advancement in Medical and Life Sciences, 3.

\section{Copyrights}

Copyright for this article is retained by the author(s), with first publication rights granted to the journal.

This is an open-access article distributed under the terms and conditions of the Creative Commons Attribution license (http://creativecommons.org/licenses/by/4.0/). 